\title{
Molting Characteristics of Crossbreds Between Alabio and Pekin Ducks
}

\author{
Susanti T, Prasetyo LH \\ Indonesian Research Institute for Animal Production, PO Box 221, Bogor 16002 \\ E-mail: triana_susie@yahoo.com
}

(Diterima 14 Januari 2015; direvisi 9 Maret 2015; disetujui 11 Maret 2015)

\begin{abstract}
ABSTRAK
Susanti T, Prasetyo LH. 2015. Karakteristik sifat rontok bulu dari persilangan itik Alabio dan Peking. JITV 20(1): 18-22. DOI: http://dx.doi.org/10.14334/jitv.v20i1.1117

Kejadian rontok bulu menyebabkan kerugian bagi peternak karena selama itu itik berhenti bertelur. Sifat rontok bulu dapat dikontrol melalui persilangan antara itik yang tidak rontok dengan itik yang rontok untuk menghasilkan itik dengan tingkat rontok bulu yang lebih rendah. Tujuan dari penelitian ini adalah untuk mengevaluasi sifat rontok bulu pada persilangan itik Alabio dan Peking. Materi yang digunakan adalah 90 ekor betina AP (hasil persilangan Alabio jantan dengan Peking betina) dan 90 betina PA (hasil persilangan Peking jantan dan Alabio betina), 25 ekor itik Alabio betina dan 25 ekor itik Peking betina. Peubah yang diamati adalah lamanya rontok bulu dan produksi telur selama 30 minggu. Data yang terkumpul dianalisis dengan ANOVA dan dilakukan perhitungan pendugaan nilai heterosis. Hasil pengamatan menunjukkan bahwa lamanya rontok bulu pada itik Peking paling tinggi dibandingkan dengan 3 genotipa lain yaitu Alabio, AP dan PA. Lamanya rontok bulu itik Peking adalah 71,31 $\pm 9,36$ hari, lebih lama $(\mathrm{P}<0,01)$ dibandingkan dengan itik Alabio, AP dan PA yaitu masing-masing 42,44 $\pm 8,59$; $43,63 \pm 4,88$; dan 49,35 $\pm 4,85$ hari. Produksi telur itik Peking $(56,41 \pm 4,59)$ lebih rendah $(\mathrm{P}<0,01)$ dibandingkan dengan 3 genotipa lainnya yaitu itik Alabio, AP dan PA yaitu masing-masing 72,48 $\pm 3,24 ; 83,75 \pm 1,39$; dan 76,12 $\pm 1,68$. Nilai heterosis lamanya rontok bulu pada itik AP lebih tinggi daripada itik PA yaitu masing-masing -23,29 dan $-13,23 \%$. Nilai heterosis produksi telur pada itik AP lebih tinggi daripada itik PA yaitu masing-masing 29,96 dan 18,12\%. Dari hasil tersebut dapat disimpulkan bahwa pembentukan bibit itik dengan produksi telur tinggi dan sifat rontok bulu yang terkendali dapat dilakukan melalui persilangan itik Alabio jantan dan Peking betina (AP) sebagai populasi dasar program pemuliaan.
\end{abstract}

Kata Kunci: Itik, Alabio, Peking, Hibrida, Rontok Bulu

\begin{abstract}
Susanti T, Prasetyo LH. 2015. Molting characteristics of crossbreds between Alabio and Pekin ducks. JITV 20(1): 18-22. DOI: http://dx.doi.org/10.14334/jitv.v20i1.1117

Molting is a problem for duck farmers, during which the ducks stop laying eggs. Molting characteristics may be altered through crossing between non-molting to molting ducks. The purpose of this study was to evaluate molting characteristics of the crossing between Alabio and Pekin ducks. The materials used were 90 female AP (Alabio males x Pekin females) and 90 female PA (Pekin males x Alabio females), 25 female Alabio and 25 female Pekin ducks. The ducks were housed in individual cages at the Indonesian Research Institute for Animal Production, Ciawi Bogor. Variables measured were the length of molting and egg production in 30 weeks, data were analyzed using ANOVA and followed by the estimation of the value of heterosis. Result showed that the molting of Pekin ducks was 71.31 \pm 9.36 days, it was longer than Alabio, AP or PA ducks, which were respectively $42.44 \pm 8.59,43.63 \pm 4.88$ and $49.35 \pm 4.85$ days $(\mathrm{P}<0.01)$. Egg production of Pekin duck $(56.41 \pm 4.59)$ was significantly lower $(\mathrm{P}<0.01)$ than that of Alabio, AP or PA, which were $72.48 \pm 3.24,83.75 \pm 1.39$ and $76.12 \pm 1.68$ respectively. The heterosis of molting period of AP was higher than that of PA (-23.29 vs $-13.23 \%)$. The heterosis of egg production of AP was higher than PA (29.96 vs $18.12 \%$ ). It is concluded that the AP crossbred could be utilized as the initial population to produce a superior line characterized by high egg production and controllable molting.
\end{abstract}

Key Words: Duck, Alabio, Pekin, Crossbreds, Molting

\section{INTRODUCTION}

There are many local breeds of ducks in Indonesia, and they can be found widely spread across the country. The local ducks as descendants of the Indian Runner have the potential of high egg production, but they have not shown their egg production optimally. This is because of the occurrence of molting during egg production periods. Molting is the loss of old feathers being replaced by the growth of new feathers. The process of molting is affected by high concentration of the prolactin hormone, which inhibits the secretion of Follicle Stimulating Hormone (FSH) and Luteinizing Hormone (LH), so there are no eggs being laid (Susanti 
et al. 2012a). In general, the incidence of molting only happens once a year, but in local ducks it may occur more than once. This phenomenon is a problem for farmers who rely on ducks as their commodity business, because continuous feeding does not guarantee enough egg production (Setioko 2005). Therefore, an effort should be made to reduce molting incidence in ducks.

Until now, the treatment of molting has been carried out through manipulation of feeding management (forced molting), but the impact of this action is temporary. Because the reduced incidence of molting through restriction of feed in parents cannot be passed on to their offspring. On the other hand, altering the incidence of molting through genetic approach is expected to give permanent impacts, so that the changes could be passed on to the next generation. The incidence of molting varies among individuals and populations, and it indicates the presence of genetic variations. Therefore, the quality improvement of ducks through controlling of the molting incidence could be done genetically.

The inheritance of a trait could be determined by conducting reciprocal crosses between male and female of specific breeds. In this research, a crossing between Alabio ducks that have high incidence of molting causing low egg production and Pekin ducks that shows lower incidence of molting and with egg production remained relatively high. This crossing is expected to alter the incidence of molting in their hybrid progeny which should be lower than the Alabio ducks. This approach has been shown by Romanov et al. (2002) who were able to reduce broodiness through crossing between Bantam chicken and White Leghorn.

Crossbreds may show hybrid vigor that could be measured quantitatively and called heterosis. The value of heterosis indicated the average performance of a hybrid population compared to the average of their parents (Noor 2010). Prasetyo \& Susanti (1997) stated that the crossbreeding program had been widely used in the livestock industry, if the desired phenotype was a combination of the existing strains, or to improve production efficiency through the use of strain-specific males and females. The crossing program of different groups of genotype could be done, among lines, strains or breeds for the purpose of forming a new breed by combining the beneficial properties into hybrid cattle to accelerate improvement of livestock productivity (Martojo 1992; Warwick et al. 1995). In other terms the crossing was performed as a strategy to take advantage of the so-called hybrid vigor. The heterosis was allegedly as a result of non-additive gene action as the dominant effect, over-dominant and epistasis (Falconer \& Mackay 1996; Noor 2010). The program was expected to show that the reciprocal crossing could be used to predict patterns of inheritance and the genes that influence the molting incidence. Therefore, the purpose of this study was to evaluate the molting characteristics of reciprocal crosses between the molting Alabio and allegedly non-molting Pekin ducks.

\section{MATERIALS AND METHODS}

\section{Research materials}

The number of observed ducks were 230 consisting of 90 female ducks PA (Pekin male x Alabio female), 90 females AP (Alabio male x Pekin female), 25 Alabio female ducks and 25 Pekin female ducks.The identity number of the male and female parents were recorded, so the father and mother of each individual of F1 progeny were known.

The rearing management and housing system of the ducks were following the operational standards that existed in the Indonesia Research Institute for Animal Production (IRIAP). During starter period the birds were fed commercial ration containing $21-22 \%$ crude protein and metabolic energy (ME) $3000 \mathrm{kcal} / \mathrm{kg}$, and during growing period with ration containing crude protein 15-16\% and ME $2500 \mathrm{kcal} / \mathrm{kg}$. During egg production the birds were given feed containing 18$19 \%$ crude protein and ME $2900 \mathrm{kcal} / \mathrm{kg}$. The amount of feed given during egg production period was the same for all ducks, about 250-300 g/bird/day. The drinking water was provided ad libitum. The ducks were housed in individual cages. Egg production was observed for 30 weeks.

Incidence of molting was the period of no eggs being laid at all, and so that the period of molting was also called a paused period of egg laying (Susanti et al. 2012b). Similarly, an adult chicken that is broody, its ovary becomes regressed and cessation of egg production follows (Liang et al. 2006; KagyaAgyemang et al. 2012). Turkey and Muscovy also experience the same thing. When they are broody, their egg production would decrease and even stop altogether (Mohamed et al. 2013).

Variables observed in this study were the length of cessation of egg laying during a period for 30 weeks. The length of cessation of laying eggs was calculated based on the number of days stopped laying, molting and back to spawn. Egg production was expressed in percentage, which is the number of eggs produced by a duck for 30 weeks divided by the number of days in 30 weeks and multiplied by $100 \%$. Analysis of Variance (ANOVA) was used to determine the significance of the effects of duck genotypes on the cessation of laying period and on egg production. ANOVA equation is as follows:

$$
\mathrm{y}_{\mathrm{ij}}=\mu+\alpha_{\mathrm{i}}+\varepsilon_{\mathrm{ij}}
$$


where:

$$
\begin{array}{ll}
y_{\mathrm{ij}} & =\text { Observed variables } \\
\mu & =\text { General mean } \\
\alpha_{\mathrm{i}} & =\text { Effect of the i-th genotype } \\
\varepsilon_{\mathrm{ij}} & =\text { Error }
\end{array}
$$

Heterosis values were estimated from the crossbreds and compared to their parental flocks, and were calculated by the following formula (Noor 2010):

$$
\begin{aligned}
& \text { Heterosis } \mathrm{AP}=\frac{\overline{\mathrm{AP}}-1 / 2(\overline{\mathrm{AA}}+\overline{\mathrm{PP}})}{1 / 2 \overline{(\mathrm{AA}}+\overline{\mathrm{PP}})} \times 100 \% \\
& \text { Heterosis } \mathrm{PA}=\frac{\overline{\mathrm{PA}}-1 / 2(\overline{\mathrm{AA}}+\overline{\mathrm{PP}})}{1 / 2 \overline{(\mathrm{AA}}+\overline{\mathrm{PP}})} \times 100 \%
\end{aligned}
$$$$
\text { where: }
$$$$
\frac{\overline{\mathrm{AP}}}{\mathrm{PA}}=\text { Average value of AP crossbred ducks }
$$$$
\overline{\mathrm{PA}}=\text { Average value of PA crossbred ducks }
$$$$
\overline{\mathrm{AA}}=\text { Average value of Alabio ducks }
$$$$
\overline{\mathrm{PP}} \quad=\text { Average value of Pekin ducks }
$$

\section{RESULTS AND DISCUSSION}

\section{Cessation of egg laying and egg production}

The length of the egg cessation due to molting and the egg production were obtained from the four genotypes of AP, PA ducks and their parental breeds, namely Pekin and Alabio ducks. The mean observations on the four genotypes of both variables are presented in Table 1.

The length of egg cessation due to molting on Pekin duck was higher than the other populations namely the Alabio, AP and PA ducks. The Pekin ducks, even in its country of origin, China or even in European countries, experienced molting after 40 weeks of production period (Cherry \& Morris 2008).The length of egg cessation due to molting in the Pekin duck was $71.31 \pm 9.36$ days, and it was longer than those of Alabio, AP and PA ducks, respectively 42.44 \pm 8.59 , $43.63 \pm 4.88$ and $49.35 \pm 4.85$ days. The length of molting in Pekin ducks in Indonesia was probably due to different environment from its original environment. This showed that the phenomenon of the interaction between genotype and environment was a disadvantage. The length of egg cessation in the study was shorter than that obtained by Purba et al. (2005) who obtained a total duration of egg cessation due to molting $90.70 \pm 12.78$ and $96.90 \pm 11.98$ days, respectively in Alabio and Mojosari ducks.

The egg production of Pekin duck was lower than the other three populations, namely Alabio, AP and PA ducks, respectively $56.41 \pm 4.59$ vs $72.48 \pm 3.24$, $83.75 \pm 1.39$ and $76.12 \pm 1.68$. Although, Pekin ducks used in this research had a long period of egg cessation due to molting and their egg production was low, but their offspring were able to express the potential of Pekin duck as superior parental. The AP ducks as the offspring of Pekin ducks had the length of egg cessation due to molting relatively shorter and higher egg production.

The average duration of egg cessation due to molting and the egg production of AP and PA crossbred ducks were better than those of both their parental Alabio and Pekin ducks. They may be caused by phenotypic diversity as the result of the presence of genetic diversity, the diversity of environments, and genetic interactions with the environment. In this study, the diversity of environments was assumed to be equal, so that the presence of diversity was only the diversity that was due to genetic factors. Genetic diversity was caused by the action of additive and non-additive genes comprising dominant (over-dominant) and epistatic genes. The high average of difference on both variables between crossbred ducks (AP and PA) and both parental (Alabio and Pekin) indicated the presence of heterosis. It was alleged that the length of egg cessation due to molting and egg production were affected by non-additive gene action namely the action of dominant and epistatic genes (Noor 2010). These results supported the notion that the nature of molting was affected by an autosomal dominant gene (Romanov et al. 2002).

Table 1. The average length of egg cessation due to molting and the egg production for 30 weeks on Alabio ducks, Pekin ducks and the reciprocal crossbreds

\begin{tabular}{lcc}
\hline \hline & \multicolumn{2}{c}{ Variables } \\
\cline { 2 - 3 } & $\begin{array}{c}\text { The length of egg cessation } \\
\text { due to molting } \\
\text { (days) }\end{array}$ & $\begin{array}{c}\text { The egg } \\
\text { production } \\
\text { (number) }\end{array}$ \\
\hline Alabio & $42.44^{\mathrm{b}} \pm 8.59$ & $72.48^{\mathrm{b}} \pm 3.24$ \\
Pekin & $71.31^{\mathrm{a}} \pm 9.36$ & $56.41^{\mathrm{c}} \pm 4.59$ \\
AP & $43.63^{\mathrm{b}} \pm 4.88$ & $83.75^{\mathrm{a}} \pm 1.39$ \\
PA & $49.35^{\mathrm{b}} \pm 4.85$ & $76.12^{\mathrm{b}} \pm 1.68$ \\
\hline
\end{tabular}

Different superscripts in the same row showed highly significant differences at the level of $\mathrm{P}<0.01$

\section{Heterosis values}

The comparison of the crossing bred result with its parental were evaluated through heterosis. Hybrid vigor (or heterosis) has become a routine tool for poultry breeders to produce progenies that exhibit more desirable phenotype than those of their parental populations (Razuki \& Al-Shaheen 2011). The heterosis values on the egg cessation due to molting and the egg 
Table 2. The heterosis values* of the egg cessation due to molting and the egg production for 30 weeks on the $\mathrm{AP}$ and PA crossbred ducks

\begin{tabular}{lcc}
\hline \hline & \multicolumn{2}{c}{ Variables } \\
\cline { 2 - 3 } & $\begin{array}{c}\text { The length of egg } \\
\text { cessation due to } \\
\text { molting }\end{array}$ & $\begin{array}{c}\text { The egg } \\
\text { production for } \\
30 \text { weeks }\end{array}$ \\
\hline AP ducks & -23.29 & 29.96 \\
PA ducks & -13.23 & 18.12 \\
\hline
\end{tabular}

* In percentage

production of the PA and AP ducks are presented in Table 2.

The heterosis value of egg cessation due to molting was negative both on the AP and PA ducks. The negative heterosis value on the length of molting was desirable, as it would shorten the duration of egg cessation. In addition, the nature of the length of egg cessation due to molting was negatively correlated with egg production, so that the high negative heterosis values were favorable. The length of egg cessation due to molting in AP ducks was lower than that of PA ducks. This means that the crosses between the Pekin female and Alabio male ducks would decrease the egg cessation due to molting, and therefore increase the egg production.

The heterosis value of egg production in AP ducks was higher than that of PA ducks, respectively 29.96 and $18.12 \%$. The heterosis value in this study was relatively high compared to that of the Prasetyo and Susanti (2000) who obtained only $11.69 \%$ on the egg production heterosis in crosses between Mojosari males and Alabio females. Similarly, the results of crosses between Alabio with Tegal who scored only $7.4 \%$ heterosis in egg production for 72 weeks (Hetzel 1983). In India, fifty percent of laying production and egg number in crossbreds up to 72 weeks of age were higher in crossbreds (indigenous $\mathrm{x}$ Khaki Campbell ducks) compared to the purebreds (Padhi 2014).

These results suggested that the reciprocal crosses between Alabio and Pekin duck could be used to increase the egg production and reduce molting trait, where the influence of the Pekin duck as a parent was instrumental in determining the egg production of the crossbreds.

The heterosis values which were high in the variable of the egg cessation due to molting and the egg production suggested that the two variables had low heritability values. In general, the value of heterosis is controlled by non-additive genes as the opposite of the heritability value which is determined by additive gene variation (Noor 2010). The low heritability value was usually associated with reproductive traits that occurred in sex cells and controlled by $\mathrm{Z}$ and $\mathrm{W}$ genes on the avian family with gametes $\mathrm{ZZ}$ for males and $\mathrm{ZW}$ for females.

The heterosis value of egg cessation due to molting and the egg production of AP ducks were higher than those of PA ducks, so it was alleged that there was the influence of genes on the sex-linkage chromosomes adrift W (maternal effect). This was different from Dun et al. (1998) who assumed the natural broodiness of chickens was controlled by genes on the sex chromosomes adrift $Z$. The higher maternal effect on the $\mathrm{W}$ chromosome than $\mathrm{Z}$ could be understood, because the mother had an additional contribution of mitochondrial DNA as the genetic material passed on to offspring as well as from nuclear DNA. Mitochondrial DNA was inherited only from the mother, because it was only found in the egg cells and not in the sperm cells.

\section{CONCLUSION}

The heterosis values of egg cessation due to molting and egg production in AP (Alabio males and Pekin females) crossbred ducks were categorized as very high. It indicated that the formation of superior ducks with high egg production and controlled molting can utilize AP hybrid ducks.

\section{ACKNOWLEDGEMENT}

We would like to thank Hamdan and $\mathrm{H}$ Miftah who assisted in rearing of the ducks and data collection.

\section{REFERENCES}

Cherry P, Morris T. 2008. Domestic duck production science and practice. London (UK): British Library.

Dunn IC, McEwan G, Okhubo T, Sharp PJ, Paton IR, Burt DW. 1998. Genetic mapping of the chicken prolactin receptor gene: A candidate gene for the control of broodiness. Br Poult Sci. 39:23-24.

Falconer DS, Mackay TFC. 1996. Introduction to quantitative genetics. 4th ed. Longman, England.

Hetzel DJS. 1983. The egg production of intensively managed Alabio and Tegal ducks and their reciprocal crosses. World Rev Anim Prod. 19:41-46.

Kagya-Agyemang JK, Shendan S, Yinzuo B, Asafa AR, Ologhobo AD, Adejumo IO, Tawinwaang T. 2012. Studies on the endocrine and neuroendocrine control of broodiness in the Yuehuang Hen. Int J Poult Sci. 11:488-495

Liang Y, Cui, J, Yang G, Leung FC, Zhang X. 2006. Polymorphisms of 5' flanking region of chicken prolactine gene. Domest Anim Endocrinol. 30:1-16. 
Martojo H. 1992. Peningkatan mutu genetik ternak. Bogor (Indones): PAU IPB, IPB Press.

Mohamed RA, Mousa-Balabel T, Elbassiouny A. 2013. Evaluation of some management procedures for controlling broodiness in Turkey and Muscovy duck. J Adv Vet Res. 3:161-166.

Noor RR. 2010. Genetika ternak. Edisi VI. Jakarta (Indones): Penebar Swadaya.

Padhi MK. 2014. Evaluation of indigenous ducks of Odisha, India. World's Poult Sci J. 70:617-626.

Prasetyo LH, Susanti T. 1997. Persilangan timbal balik antara itik Tegal dan Mojosari: I. Awal pertumbuhan dan awal bertelur. JITV. 2:152-156.

Prasetyo LH, Susanti T. 2000. Persilangan timbal balik antara itik Alabio dan Mojosari: Periode awal bertelur. JITV. 5:210-214.

Purba M, Hardjosworo PS, Prasetyo LH, Ekastuti DR. 2005. Pola rontok bulu itik betina Alabio dan Mojosari serta hubungannya dengan kadar lemak darah (Trigliserida), Produksi dan Kualitas Telur. JITV. 20:96-205.
Razuki WM, Al-Shaheen SA. 2011. Use of full diallel cross to estimate crossbreeding effects in laying chicken. Int $\mathrm{J}$ Poult Sci. 10:197-204.

Romanov MN, Talbot RT, Wilson PW, Sharp PJ. 2002. Genetic control of incubation behavior in domestic hen. Poult Sci. 81:928-931.

Setioko AR. 2005. Ranggas paksa (forced molting): Upaya memproduktifkan kembali itik petelur. Wartazoa. 15:119-127.

Susanti T, Noor RR, Hardjosworo PS, Prasetyo LH. 2012a. Relationship between the prolactin hormone level with molting and duck egg production. J Indones Trop Anim Agric. 37:161-167.

Susanti T, Noor RR, Hardjosworo PS, Prasetyo LH. 2012b. Keterkaitan kejadian dan lamanya rontok bulu terhadap produksi telur itik hasil persilangan Pekin dengan Alabio. JITV. 17:112-119.

Warwick EJ, Maria AJ, Hardjosubroto W. 1995. Pemuliaan ternak. Yogyakarta (Indones): Gadjah Mada University Press. 